\title{
Nominal Interest Rate, Inflation and Money Market Link in Bangladesh: An Econometric Analysis
}

ISSN: 2311-8636 (Print)

ISSN: 2312-2021 (Online)

Licensed:

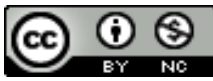

Source of Support: Nil

No Conflict of Interest: Declared

*Email for correspondence: ripon.ar@gmail.com

Sanjida Akter Chowdhury ${ }^{1}$, Md.Yousuf ${ }^{2}$, Md. Nezum Uddin ${ }^{3 *}$, Mohammed Jashim Uddin ${ }^{4}$

${ }^{1} \mathrm{MSS}$ in Economics and Banking, Department of Economics \& Banking, International Islamic University Chittagong (IIUC), BANGLADESH

${ }^{2}$ Assistant Director, Chief Economist's Unit, Bangladesh Bank, Head office, Dhaka, BANGLADESH

${ }^{3,4}$ Assistant Professor, Department of Economics \& Banking, International Islamic University Chittagong (IIUC), BANGLADESH

\section{ABSTRACT}

This paper pursues to establish a connection among the nominal interest rate, the money market, and the inflation rate in Bangladesh using monthly time series data from June 2005 to March 2019. Because some data are stationary at the level and others are stationary at the 1st difference, the ARDL model is applicable for checking the link. There is a strong positive short-term and long-term relationship between inflation and nominal interest rates, suggesting that Bangladeshi data support the Fisher hypothesis for that time. For this study, the T bill, the call money rate is used as a measure of the money market. The research indicates that regulators should concentrate on call money rates in short-term and T-bill and call money rates in the longterm to control Bangladesh's nominal interest rate.

Keywords: Inflation rate, Nominal interest rate, Unit root test, Johansen co-integration test, ARDL model, Bound test, Granger causality test

\section{INTRODUCTION}

For an extended period, the relationship among the macroeconomic policy variables was an enticing issue for both financial analysts and macroeconomists. The paper explores the link between Bangladesh's inflation, interest rate, and money market.

The money market is vital to funding markets for financial institutions. It provides a medium for the center of short-term loanable funds among financial institutions like Treasury bill, repurchase agreement, bill of exchange, commercial paper, short-term government securities, call money, etc. It is generally considered the most active venue where government, as well as other securities, are exchanged within a short period (Rudiger Dornbusch, Stanley Fischer, \& Startz, 2011).

There is a very active money market in Bangladesh where a variety of instruments are traded. In FY 2018, the overall money market faced mild liquidity pressure, as evident from 
an upward trend in the call money rate in Bangladesh. Call money rate varying from $2.96 \%$ to $4.40 \%$ over the same period. The repo interest rate decreased from $6.75 \%$ to $6.00 \%$ as of April 2018. In FY18, the weekly auctions of 91-day, 182-day, and 364-day Treasury bills are used and continued as essential debt management tools. The weighted average maturity yield extended from 0.73 to 4.83 percent compared to the permitted bids. A total of 2446 attempts were received in FY17, amounting to BDT 1562.76 billion, of which BDT 505.00 billion were approved (Bangladesh Bank, 2019).

In many countries, inflation has become a well-wrapped phenomenon (Mohammad Zoynul Abedin, and, \& Parvin, 2013). Gradual upward changes in prices, namely, inflation is highly unwanted (Gul \& Ekinci, 2006). A central goal of conventional monetary policy is to control inflation because low inflation leads to better resource allocation and promotes fast and stable economic growth (Mohammad Zoynul Abedin et al., 2013). A downward trend in year-on-year inflation has been reported from the start of FY2013-14. In FY2013-14, inflation decreased from 7.35\% year-on-year to 5.44\% in FY2016-17 but marginally increased to 5.78\% in FY2017-18 (Bangladesh Economic Review, 2019). Inflation peaked with food inflation hitting 7.9\% in September 2017, a point not seen since July 2014.

The general inflation index has since been on a decelerating trend mainly due to declining food price increases. Overall, inflation dropped from 6.1 percent in September 2017 to 5.5 percent in February 2019, about every month after that, barring January-February 2019. Food inflation accelerated the deceleration to 5.4 percent (The World Bank, 2019). Point to point monthly average rate of inflation was 5.50\% in October 2019 (Dhaka Tribune, 2019).

In October, the inflation rate fell slightly from 5.54 percent in September to 5.47 percent, and it was lowered to $5.35 \%$ last December due to a decline in the price of a particular food and non-food items except onion. Given the increase in the price of onion, the overall price of vegetables and fruits dropped slightly in October compared to September (The Daily Star, 2019).

Since the interest rate is the center of monetary policy, this works as one of the principal policy instruments but not just as passive reflectors of the money supply. Interest rates were also widely popular in developing nations as policy tools. The nominal interest rate works as the bank interest rate, whereas the purchasing power enhancement roles as the real interest rate. (MANKIW, 2009). If $i_{n}$ indicates the nominal interest rate, $i_{r}$ the real interest rate, and $\gamma$ the inflation rate, then the connection among these three variables can be ascribed as, $i_{r}=i_{n}-\gamma$, or $i_{n}=i_{r}+\gamma$. If we divide the nominal interest rate into those two sections, we can use this equation to build a theory that explains the nominal interest rate as the Fisher effect or the Fisher hypothesis.

If the real interest rate remains unchanged, the Fisher hypothesis observes a one-for-one connection between the inflation rate and the nominal interest rate. For instance, a 10\% increase in the nominal interest rate due to a $10 \%$ increase in the inflation rate (MANKIW, 2009). The reliability of the Fisher effect also has significant monetary policy ramifications and must be taken into account by central banks (Awomuse \& Alimi, 2012).

A considerable amount of research centered on the correlation between the nominal interest rate and inflation. Crowder and Hoffman (1996) showed the evidence of the Fisher hypothesis in the short-run by using the US inflation rate and three-month quarterly T-bill rate. They often find that the ordering triggered by the long term Granger varies running from inflation to nominal rate, and this indicates that the information which contains inflation rate paves the way for the possible route of the nominal interest rate. 
But very few studies have been found to explore the connection between the nominal interest rate and the money market. This study is an attempt to cover this gap by exploring the association between interest rate, inflation, and money market in Bangladesh. Information about relevant data has been supplied in the methodology section.

\section{LITERATURE REVIEW}

The relation between the nominal interest rate and inflation is checked by several researchers in different regions and different periods. The nominal interest rate and inflation connection ware checked by Fama (1975) using the US 1 month T- bills, inflation rates, expected real of return, CPI data from January 1953 to July 1975. The author found a one- to six-month variation for nominal rates of interest and suggested that variation might be occurred due to variation in purchasing power.

Crowder and Hoffman (1996) presence of long- run equilibrium between two macroeconomic variables, namely called nominal interest rates and inflation. The authors used three month T- bill, implicit price deflator, and expenditures data in and after tax setting between January 1952 and April 1991 in the US economy. They found the long -run relation between them. St-Amant (1996) explores the connection between real ex-ante interest rate fluctuations and inflation expectations assuming that nominal interest rates and inflation expectations are maintained long-term one-to-one relation. The study finds a huge fluctuation in ex-ante real interest rates in 1994 and the beginning half of 1995 due to higher inflation expectations of the one- year and 10-years bond rate in the 1970s as well as the early 1980s. Berument and Malatyali (2001) examines Turkey's determinants of inflation from 1989 to 1998 by using the ARCH model and GARCH model.

The study found one to one link with nominal interest rate and expected inflation means the constancy in the real interest rate. Booth and Ciner (2001) finds a similar results for the rates of Eurocurrency as well as expected inflation between nine European countries and the US. Atkins (2002) investigated structural breaks between the inflation rate and the nominal interest rate used Canadian and U. S data. The study result shows the data is consistent with three breaks in the Canadian interest rate average and two breaks in the US interest rate. Önel (2005) used same methodology like Atkins for Turkish CPI and timedeposits interest rate (90 days) from January 1980 to December 2004 and little evidence of mean breaks for interest rate data has been found, while inflation rate data are consistent with two breaks at 1987:9 and 2000:2. Lardic and Mignon (2003) studied the Fisher hypothesis to show the link between the nominal interest rate, and inflation and they used quarterly data from 1970 to 2001 in G7 countries. The result finds the existence of the Fisher hypothesis at a majority of G7 countries, although the general concept of cointegration is too rigid to hold up the Fisher effect. Maki (2005) checked whether the long-term link between the nominal interest rate and inflation rate exists in Japan for the period of 1963:2 to 2002:1. The author finds that the Engle-Granger method cannot obtain the result of cointegration when symmetric adjustment is assumed.

Lanne (2006) used a nonlinear bivariate mixture autoregressive model by applying quarterly US data from February 1953 to April 2004 to test whether there exists any relation between the inflation rate and Treasury bill ( 3 months). The study finds the presence of a common nonlinear component that affects a large part of its longevity, even though the real interest rate lacks that component in the long run, which indicates a one-for-one change of the nominal interest rate and inflation. The correlation between the interest rate and inflation has been tested by Asgharpur, Kohnehshahri, and Karami (2007) in some selected 
Islamic countries from 2002 to 2005 using panel data for the analysis and found a unidirectional causality between the variables. Ayub, Rehman, Iqbal, Zaman, and Atif (2014) got the similar results for the Pakistan economy using time series data between 1973 and 2010. Nezhad and Zarea (2007) studied the causality between the rate of interest, and they used the ARDL model for Iran's economy. They also applied Granger causal relationship for the same variables from 1959 to 2002 and found the rate of interest rises due to the cause of inflation although the opposite is not found to exist. Lee (2009) used same variables like Maki for Singapore economy from the $1^{\text {st }}$ quarter 1976 to $4^{\text {th }}$ quarter 2006 and found the presence of a positive connection between the variables that fail to accept the full Fisher effect's concept. Moreover, the study found the presence of price dilemma in the Singapore market. Mahdi and Masood (2011) observed a long-term close association between quarterly housing prices and inflation in Iran from 1989 to 2007. Teker, Alp, and Kent (2012) evaluated the interest rates for deposits and CPI if there is any association between them for Turkey's economy. They found the ECM coefficient to be -0.14 and -0.83 when inflation and interest rate gap is less than 11 percent and more than 11 percent, respectively. Hossain and Islam (2013) investigated inflation factors for Bangladesh from 1990 to 2010, using the Ordinary Least Square (OLS) approach. They found that one year lagged interest rate directly and substantially impact on inflation where money supply works to control inflation.

The nature of both short- and long-term Fisher Effect and Price Puzzle was examined by Edirisinghe, Sivarajasingham, and Nigel (2015) for the Sri Lankan economy. They found a strong positive akin to nominal interest rates as well as expected inflation for the short-run, and the full Fisher Effect was absent in the meantime. But they observed the existence of the Price Puzzle not only for the short-run but also for the long-run. The casual relation of interest rates and inflation is investigated by Uddin, Alam, and Alam (2008) using monthly data from August 1996 to December 2003 in Bangladesh, and they applied the OLS estimation method to get the result. The authors find the non-presence of the long-run link among these desired variables and explained the random behaviors of variables are responsible in this regard. The results suggest as there is no significant relation with the interest rate to cause inflation, the government process to calculate inflation-based interest rate does not work accurately.

Maitra (2018) explores the position of 91-day, 364-day treasury bills (TBs), call money rate, money supply, income and exchange rate. The analysis reveals that the treasury bills and call money rate play a major role in India. Interest rates on TBs are tied to proportional increases in money supply and projected nominal revenue.

\section{Methodology}

\section{Data Information}

The study has collected data from annual reports published by Bangladesh Bank. Data from June 2005 to March 2019 are collected in this regard. Landing rate (LR) is used as the nominal rate of interest that is paid by the financial institution. 91 days Treasury bill rate (TB), repurchase agreement $(\mathrm{RP})$, call money rate $(\mathrm{CM})$ are used as the instrument of money market, and inflation rate (IR) is measured by using the consumer price index. The following function links the variables:

$L R=f(I R, T B, R P, C M) \mathrm{f}(\mathrm{IR}, \mathrm{TB}, \mathrm{RP}, \mathrm{CM})$

$\mathrm{m}$ of the model is- $\log L R=\alpha_{0}+\alpha_{1} \log I R+\alpha_{3} \log T B+\alpha_{4} \log R P+\alpha_{5} \log C M+\mu_{t}$

Here, $\mu_{t}=$ Stochastic term 


\section{Method selection framework}

One assumption we hold is that the variables in our equations remain stationary throughout the analysis. For the time being, we note that a stationary variable is neither explosive nor trendy, nor wandering without going back to its meaning (Hill, Griffiths, \& Lim, 2018). The statistical method used to assess whether a series stationary is called 'unit root test' (Asgharpur et al., 2007).

The widely used unit root test methods are Augmented Dickey-Fuller, Phillipse-Perron, and KPSS tests (Asgharpur et al., 2007). In practice it is difficult to choose the most suitable unit root test. Ender (1995) stated the use of the Augmented Dickey - Fuller test as a safe choice of the unit root. The Augmented Dickey-Fuller (ADF) test is commonly used for unit root (Ayub et al., 2014). We, therefore, carried out the ADF test to check stationary. Let, we've got a series a, $Y_{t}$ to check the unit root. The ADF model can be expressed as:

$\Delta Y_{t}=\alpha+\delta Y_{t-1}+\sum_{i=1}^{k} \gamma_{i} Y_{t-i}+\mu_{t}$

Where,

$\delta=\beta-1$

$\beta$ is the Coefficient of $Y_{t-1}$

$\Delta Y_{t}$ is the first difference of $Y_{t}$, i.e. $Y_{t}-Y_{t-1}$

The null hypothesis of $\mathrm{ADF}$ is $\delta=0$ means series are non-stationary. The series is nonstationary if we don't reject null while rejection means the series is stationary.

Table 1: Augmented Dickey-Fuller t- statistics test

\begin{tabular}{|c|c|c|c|c|c|c|}
\hline Variables & \multicolumn{2}{|c|}{ Only Constant(C) } & Decision & \multicolumn{2}{|c|}{ Constant \& Trend(C \&T) } & Decision \\
\cline { 5 - 6 } & At level & At $1^{\text {st }}$ & & At level & At $1^{\text {st }}$ & \\
& & Difference & & & & \\
& & & & Difference & \\
\hline TB & $(-0.671904)$ & $(-8.42507)$ & Non & $(-1.019076)$ & $(-8.510797)$ & Stationary \\
& $(0.8486)$ & $(0.0000)$ & stationary & $(0.9366)$ & $(0.0000)$ & \\
\hline CM & $(-4.802701)$ & $(-12.07566)$ & Stationary & $(-5.255663)$ & $(-12.04520)$ & Stationary \\
& $(0.0001)$ & $(0.0000)$ & & $(0.0001)$ & $(0.0000)$ & \\
\hline IR & $(-2.672386)$ & $(-10.55595)$ & Stationary & $(-2.946794)$ & $(-10.52434)$ & Stationary \\
& $(0.0812)$ & $(0.0000)$ & & $(0.1510)$ & $(0.0000)$ & \\
\hline LR & $(0.127050)$ & $(-4.92277)$ & Non & $(-4.566111)$ & $(-5.727388)$ & Stationary \\
& $(0.9661)$ & $(0.0001)$ & stationary & $(0.0022)$ & $(0.0000)$ & \\
\hline RP & $(-2.012578)$ & $(-9.106349)$ & Non & $(-2.436552)$ & $(-9.554429)$ & Stationary \\
& $(0.2812)$ & $(0.0000)$ & stationary & $(0.3591)$ & $(0.0000)$ & \\
\hline
\end{tabular}

*Source: Author(s) own calculation using E-views-9

The result of Table-1 exhibits that TB, LR, and RP data are non-stationary at level, but these are showing stationary at $1^{\text {st }}$ difference. On the other hand, CM and IR data are showing stationary at level.

Therefore data are mixed order. Where interest variables are of a mixed order of integration ARDL model is suitable for analyzing the data from the time series (Ayub et al., 2014).

Now check the short term and long term reliability of the ARDL model. Examine the following results in Table 2 . 
Table 2: Reliability of ARDL

\begin{tabular}{|c|c|c|}
\hline \multicolumn{3}{|c|}{ F-Statistic=5.665129 } \\
\hline Level of Significance & Lower Bound & Upper Bound \\
\hline $5 \%$ & 4.94 & 5.73 \\
\hline \multicolumn{2}{|c|}{ R-Squared $=0.998289$, Durbin Watson Stat=2.232790 } \\
\hline
\end{tabular}

*Source: Author(s) own calculation using E-views-9

Since R-squared value is not greater than Durbin- Watson stat value and it is almost 99\%, the model has high explanatory power. F-statistic value is 5.66 greater than the lower bound 4.94, and then there is a presence of long-run connection.

\section{Estimated REsults}

The short run coefficients results of ARDL are presented in Table -3. The cointegration equation suggests that LR rises by 43 basis point, 32 point, 39 point due to 1 unit change in IR, TB, and CM, respectively, and decreased by 27 point by RP but short-run estimated result revealed that $\mathrm{RP}$ and $\mathrm{TB}$ are insignificant.

The coefficient of $E C T_{t-1}$ is in the correct sign and significant. Its value is little enough (0.052106) - it means that approximately $5 \%$ of the landing rate of the previous year's shock returned to the long-run balance in the current year.

Table 3: Co-integration Estimation and ECM

\begin{tabular}{|l|c|c|c|}
\hline Variable & Coefficient & t-statics & p-value \\
\hline $\mathrm{D}(\mathrm{IR})$ & 0.037589 & 2.015022 & 0.0474 \\
\hline $\mathrm{D}(\mathrm{RP})$ & -0.014184 & -0.346195 & 0.7301 \\
\hline $\mathrm{D}(\mathrm{TB})$ & 0.016704 & 1.250627 & 0.2149 \\
\hline $\mathrm{D}(\mathrm{CM})$ & 0.020615 & 3.430025 & 0.0010 \\
\hline$E C T_{t-1}$ & -0.052106 & -2.967898 & 0.0040 \\
\hline Cointeq= LENDING RATE - $(0.4370 *$ IR- \\
$0.2722^{*}$ REPO+0.3206*TB+0.3956*CALLMONEY+5.4488) \\
\hline
\end{tabular}

*Source: Author(s) own calculation using E-views-9

The findings for the long-run are reported in Table-4. Inflation coefficient is 0.43 and statistically significant at $5 \%$, which implies that a $1 \%$ rise in the inflation rate (IR) would lead to a long run increase of $0.43 \%$ in the nominal interest rate.

The repo rate (RP) coefficient is found to be -0.27 but which is statistically insignificant. Estimates of Treasury bill (TB) and call money (CM) are positive and significant at the $10 \%$ level. One percentage point change in Treasury bill and call money will increase the nominal interest rate by $0.32 \%$ and $0.39 \%$, respectively

Table 4: Long Run Estimates of ARDL

\begin{tabular}{|c|c|c|c|c|}
\hline Variable & Coefficient & Std. Error & t-Statistic & Prob. \\
\hline Inflation Rate (IR) & 0.436983 & 0.145534 & 3.002611 & 0.0036 \\
\hline Repo Rate (RP) & -0.272207 & 0.820637 & -0.331703 & 0.7410 \\
\hline T Bill (TB) & 0.320571 & 0.190995 & 1.678430 & 0.0973 \\
\hline Call Money Rate (CM) & 0.395635 & 0.215014 & 1.840049 & 0.0696 \\
\hline C & 5.448774 & 5.279243 & 1.032113 & 0.3053 \\
\hline
\end{tabular}

*Source: Author(s) own calculation using E-views-9 
Granger casualty test is used to determine the direction of causality, and the findings are provided in Table-5. The null hypothesis of no causality is checked by F statistic and probabilities values.

It is clear that uni-directional causality is found from inflation to landing rate at the 5 percent level; this one to one relation between nominal interest rates and inflation confirms the existence of the Fisher effect in Bangladesh.

Now check other relationships. Table- 5 shows that there is a uni-directional relation from call money to lending rate, and bi-directional causalities have found between Treasury bill and lending rate, repurchase agreement, and lending rate that shows a link between money market and lending rate in the country.

Table 5: Granger Causality Test

\begin{tabular}{|l|c|c|}
\hline Causality & F-statistics & p-value \\
\hline $\mathrm{IR} \rightarrow \mathrm{LR}$ & 7.25898 & 0.0013 \\
\hline $\mathrm{TB} \rightarrow \mathrm{LR}$ & 4.73667 & 0.0117 \\
\hline $\mathrm{CM} \rightarrow \mathrm{LR}$ & 8.64580 & 0.0004 \\
\hline $\mathrm{RP} \rightarrow \mathrm{LR}$ & 3.66372 & 0.0299 \\
\hline $\mathrm{LR} \rightarrow \mathrm{RP}$ & 7.86097 & 0.0008 \\
\hline $\mathrm{TB} \rightarrow \mathrm{IR}$ & 2.63272 & 0.0764 \\
\hline $\mathrm{IR} \rightarrow \mathrm{TB}$ & 6.83928 & 0.0016 \\
\hline $\mathrm{IR} \rightarrow \mathrm{CM}$ & 3.53729 & 0.0316 \\
\hline $\mathrm{IR} \rightarrow \mathrm{RP}$ & 8.13751 & 0.0005 \\
\hline $\mathrm{RP} \rightarrow \mathrm{IR}$ & 6.73057 & 0.0018 \\
\hline $\mathrm{CM} \rightarrow \mathrm{TB}$ & 3.73858 & 0.0268 \\
\hline $\mathrm{TB} \rightarrow \mathrm{CM}$ & 5.51886 & 0.0052 \\
\hline $\mathrm{TB} \rightarrow \mathrm{RP}$ & 2.60004 & 0.0802 \\
\hline
\end{tabular}

*Source: Author(s) own calculation using E-views-9

Heteroscedasticity may typically be assumed in cross-sectional data analysis, which could nullify normal estimation techniques, and serial correlation is a potential problem in the time series (Hill et al., 2018). Table-6 estimates possible heteroscedasticity and serial correlation problems are verified respectively by Breusch-Pagan-Godfrey and BreuschGodfrey Serial Correlation LM test.

Table 6: Heteroscedasticity and Autocorrelation Check

\begin{tabular}{|c|c|}
\hline \multicolumn{2}{|c|}{ Breusch-Pagan-Godfrey Heteroscedasticity Test } \\
\hline F-statistic $=2.359758$ & Prob.F $(6,77)=0.0381$ \\
\hline Obs. ${ }^{*}$ R-squared $=13.04670$ & Prob. Chi squared $(6)=0.0423$ \\
\hline Akaike info criterion $=-5.660244$ & Prob.F-statistic $=0.038124$ \\
\hline Schwarz criterion $=-5.457676$ & Durbin Watson stat $=2.302750$ \\
\hline Scaled explained SS= 31.15647 & Prob.chi-squared $(6)=0.0000$ \\
\hline \multicolumn{2}{|c|}{ Breusch-Pagan-Godfrey Serial Correlation LM Test } \\
\hline F-statistic $=0.444444$ & Prob.F $(1,76)=0.5070$ \\
\hline Obs $*$ R-squared $=0.488372$ & Prob.chi-square( 1$)=0.4847$ \\
\hline
\end{tabular}

*Source: Author(s) own calculation using E-views-9

The above finding reveals that the chi-square for the chosen lag is of less than the 5 percent significance level that ensures the null hypothesis; no Heteroscedasticity cannot be 
dismissed.Breusch-Godfrey Serial Correlation LM test is examined to see if there is any autocorrelation. The F value of the LM test is negligible at the 5\% level, indicating that there is no autocorrelation in the model.

The CUSUM and CUSUM square are used to assess the stability of the long run coefficient. Since the blue line remains in between both red lines in Figure-1 and 2, the CUSUM plot remains within the 5 percent limit that confirms the long-term stability of the coefficient.

Figrue 1: CUSUM Stability Test

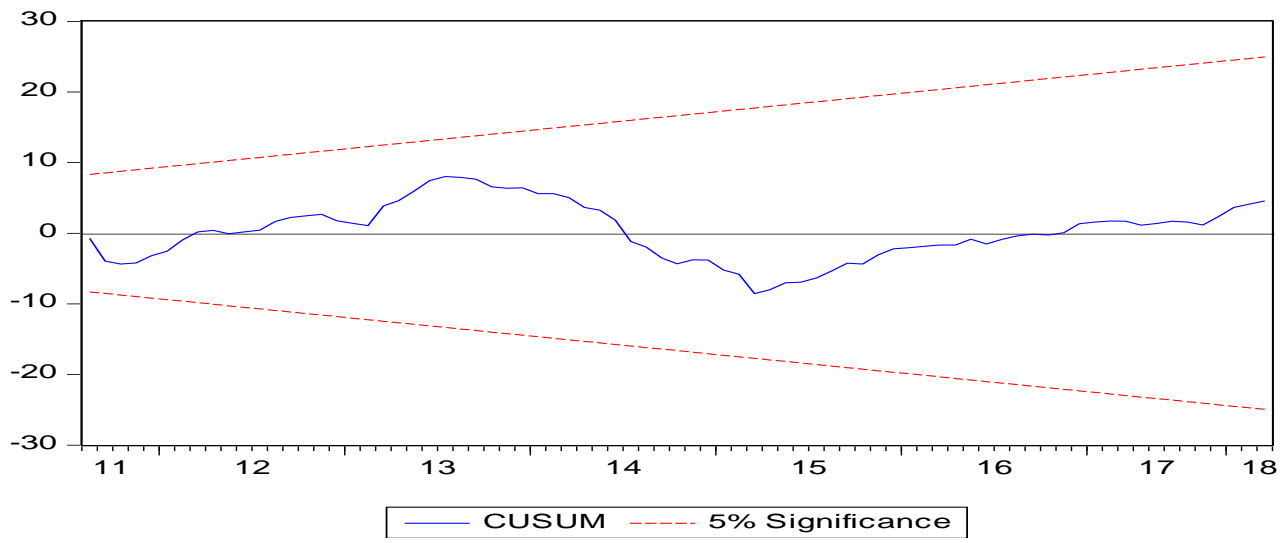

Figrue 2: CUSUM-Square Stability Test

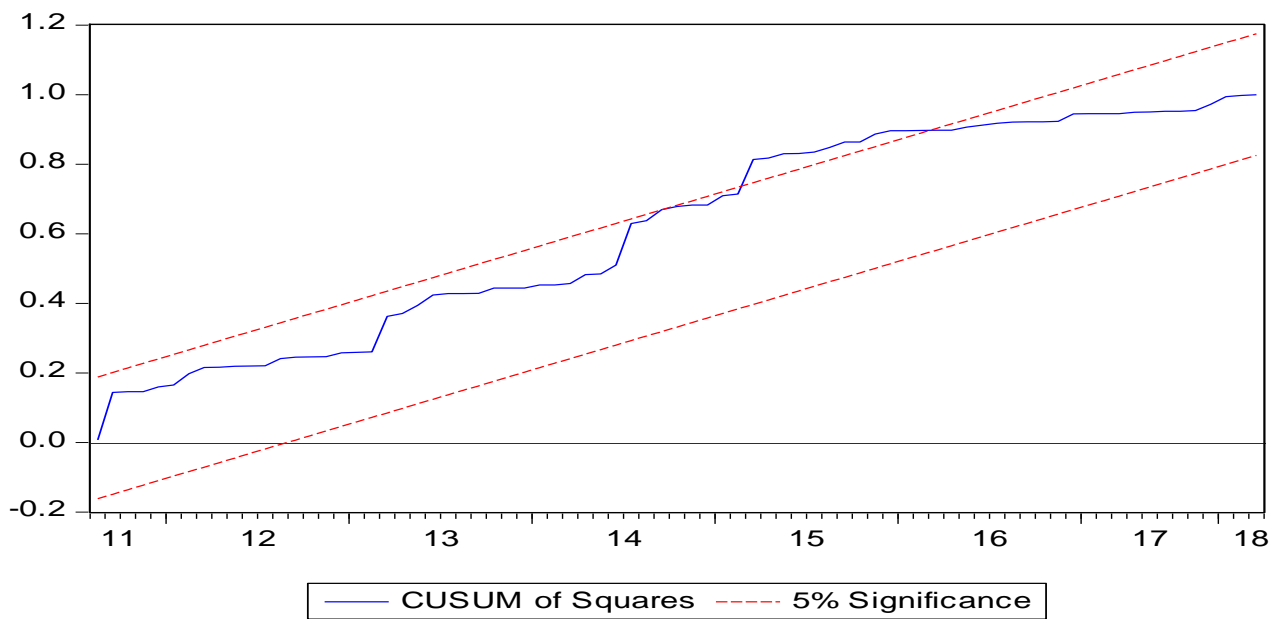

\section{Conclusion and Policy Recommendations}

The research aims at inspecting the relation between Bangladesh's nominal interest rate, inflation, and money market. Empirical results under the ARDL framework suggest the existence of short and long-run ties among nominal interest rates, inflation, and money market. The data for the period of June 2005 to March 2019 has supported the Fisher hypothesis, i.e., a one-to-one association between the nominal interest rate and inflation is found. The call-money rate only impacts the nominal interest rate in the short term, but the T-bill and repo rate does not affect. By contrast, in the long run, T-bill and call money rate 
can influence the nominal interest, but the repo rate does not have any effect. So policymakers of the country should think about call money in the short run and the long term they have to choose call money and Treasury bill to control the nominal interest. A uni-directional causality has been found from inflation to nominal interest rate, and it suggests a one-to-one relationship between inflation and nominal interest rate. The Fisher effect is satisfied by Bangladeshi data. A uni-directional link has been found between call money and landing rate and Treasury bill and lending rate. The presence of bi-directional causality is observed between the repo rate and the nominal interest rate.

\section{REFERENCES}

Annual Report, Bangladesh Bank, 2019

Annual Report, Bangladesh Economic Review, 2019

Asgharpur, H., Kohnehshahri, L. A., \& Karami, A. (2007). The relationships between interest rates and inflation changes: An analysis of long-term interest rate dynamics in developing countries.

Atkins, F. (2002). Multiple structural breaks in the nominal interest rate and inflation in Canada and the United States. The University of Calgary, http://www. econ. ucalgary. ca/research/research. htm.

Awomuse, B. O., \& Alimi, S. R. (2012). The Relationship between nominal interest rates and inflation: New Evidence and Implication for Nigeria.

Ayub, G., Rehman, N., Iqbal, M., Zaman, Q., \& Atif, M. (2014). Relationship between inflation and interest rate: evidence from Pakistan. Research Journal of Recent Sciences ISSN, 2277, 2502.

Berument, H., \& Malatyali, K. (2001). Determinants of interest rates in Turkey. Russian \& East European Finance and Trade, 37(1), 5-16.

Booth, G. G., \& Ciner, C. (2001). The relationship between nominal interest rates and inflation: international evidence. Journal of Multinational Financial Management, 11(3), 269-280.

Crowder, W. J., \& Hoffman, D. L. (1996). The long-run relationship between nominal interest rates and inflation: the Fisher equation revisited. Journal of money, credit and banking, 28(1), 102-118.

Edirisinghe, N., Sivarajasingham, S., \& Nigel, J. (2015). An empirical study of the Fisher Effect and the dynamic relationship between inflation and interest rate in Sri Lanka. International Journal of Business and Social Research, 5(1), 47-62.

Fama, E. F. (1975). Short-term interest rates as predictors of inflation. The American Economic Review, 269-282.

Gul, E., \& Ekinci, A. (2006). The causal relationship between nominal interest rates and inflation: The case of Turkey.

Hill, R. C., Griffiths, W. E., \& Lim, G. C. (2018). Principles of econometrics: John Wiley \& Sons.

Hossain, T., \& Islam, N. (2013). An economic analysis of the determinants of inflation in Bangladesh. The International Journal of Social Sciences, 11(1), 29-36.

Lanne, M. (2006). Nonlinear dynamics of interest rate and inflation. Journal of Applied Econometrics, 21(8), 1157-1168.

Lardic, S., \& Mignon, V. (2003). Fractional cointegration between nominal interest rates and inflation: a re-examination of the fisher relationship in the G7 countries. Economics Bulletin, 3(14), 1-10.

Lee, K. F. (2009). An empirical study of the fisher effect and the dynamic relation between nominal interest rate and inflation in Singapore. The Singapore Economic Review, 54(01), 75-88.

Mahdi, S., \& Masood, S. (2011). The long run relationship between interest rates and inflation in Iran: Revisiting Fisher's hypothesis. Journal of Economics and International Finance, 3(14), 705. 
Maitra, B. (2018). Determinants of nominal interest rates in India. Journal of Quantitative Economics, 16(1), 265-288.

Maki, D. (2005). Asymmetric adjustment of the equilibrium relationship between the nominal interest rate and inflation rate. Economics Bulletin, 3(9), 1-8.

Mankiw, N. G. (2009). M a c r o e c o n o m i c s (E. V. E. N. T. H. E. D. I. T. I. O. N Ed.): Worth Publishers.

Mohammad Zoynul Abedin, and, F. E. M., \& Parvin, S. (2013). Inflation behavior: evidence from Bangladesh. Bangladesh research publications journal, 8(1), 07-17.

Nezhad, M. Z., \& Zarea, R. (2007). Investigating the causality Granger relationship between the rates of interest and inflation in Iran. Journal of Social Science, 3(4), 237-244.

Önel, G. (2005). Testing for multiple structural breaks: an application of Bai-Perron test to the nominal interest rates and inflation in Turkey. Dokuz Eylül Üniversitesi İktisadi İdari Bilimler Fakültesi Dergisi, 20(2), 81-94.

Rudiger Dornbusch, Stanley Fischer, \& Startz, R. (2011). Ma c r o e c o n o m i c s (E. Edition Ed.): McGraw-Hill.

St-Amant, P. (1996). Decomposing US nominal interest rates into expected inflation and ex ante real interest rates using structural VAR methodology.

Teker, D., Alp, E. A., \& Kent, O. (2012). Long-Run Relation between Interest Rates and Inflation: Evidence from Turkey. Journal of Applied Finance and Banking, 2(6), 41.

Uddin, G., Alam, M., \& Alam, K. (2008). An Empirical Evidence of Fisher Effect in Bangladesh: A TimeSeries Approach. ASA University Review,(ISSN: 1997-6925), 2(1), 1-8.

Publish Online and Print Version Both

Online Archive: https:/ /i-proclaim.my/journals/index.php/ajhal/issue/archive 